\title{
Comparative Review of Crude Protein and Amino Acid Composition of Some Leguminous Seeds Grown in Nigeria
}

\section{Matthew Olaleke Aremu1 ${ }^{1}$, Saratu Stephen Audu², Benedict Lyambee Gav ${ }^{3}$}

\author{
${ }^{1}$ Department of Chemical Sciences, Federal University Wukari, PMB 1020, Nigeria \\ ${ }^{2}$ Department of Chemistry, Nasarawa State University, PMB 1022, Keffi, Nigeria \\ ${ }^{3}$ Department of Chemistry, Federal University of Agriculture, PMB 2373, Nigeria
}

\begin{abstract}
Legumes are some of the low-priced sources of protein-rich foods that have been found important in alleviating protein malnutrition especially in developing countries. Amino acids are the basic structural building units of proteins. They form short polymer chains called peptides or polypeptides which in turn form structures called proteins. The most common methods of determining nitrogen in foods are Kjeldahl, Formol titration, Dyebinding, Lowry, Biuret and Spectroscopic methods while amino acid composition is usually determined using ionexchange chromatography on hydrolyzed and derivatized protein in food material. Crude protein and amino acid composition of some Nigerian leguminous seeds were critically reviewed in this write up. The selected legumes are; Cajanus cajan, Glycine max, Vigna unguiculata, Arachis hypogea, Vigna subterranea, Kerstingiella geocarpa, Sphenostylis sternocarpa, Phaseolus coccineus, Phaseolus lunatus, Citrulus vulgaris and Phaseolus vulgaris. The review shows that the protein content of legumes varies between $11.6-52.6 \%$. The most abundant amino acids are glutamic and aspartic acids. The total essential amino acids (TEAA) range between $41.28-68.85 \%$, total nonessential amino acids (TNEAA) range between 31.50 - 58.72\% and total acidic amino acids (TAAA) between 14.30 $-40.47 \%$ for all the legumes reviewed. Generally, leguminous seeds are good sources of most of the essential amino acids therefore they are highly suitable for the fortification of cereal products mostly used as weaning foods for children in most African countries.
\end{abstract}

Keywords: Protein Content, Amino Acid Composition, Legumes

\begin{abstract}
Introduction
Protein is the principal component of all living cells and is practically important in all aspects of cell structure and functions [1]. Proteins are large group of organic molecules that are essential to the structure and functioning of all living things. A typical protein is a large molecule consisting of one or more long chains of amino acids that are folded and twisted into complicated shapes adapted to the specific job that each performs [2]. In addition, some proteins contain small quantities of sulphur, phosphorus and minerals. Plants have the ability to synthesis proteins from inorganic nitrogen sources such as ammonia, nitrate and nitrite. Thus, all animal life either directly or indirectly depends on plants to satisfy its protein needs [3].
\end{abstract}

In addition to being components of foods, proteins are involved in greater variety of functions than any other type of molecules in life. Some proteins function as biocatalysts (enzymes) which catalyze chemical reactions [4] and hormones to regulate chemical reactions in the body. Life processes, such as growth, digestion and metabolism, excretion and conversion of chemical energy to mechanical energy/work are all controlled by enzymes and hormones [1]. Proteins are transport agents. Blood plasma proteins and haemoglobin regulate the osmotic pressure and $\mathrm{pH}$ of the body fluids. Antibodies, the natural defence agents against invasion of foreign substances (microbes) that cause various diseases, are proteins [5].

Amino acids are the building blocks of protein. An amino acid is any molecule that contains both amino and carboxylic acid functional groups. Their value as biological building blocks stems from the fact that amino acids can join together into long chains by

This article is published under the terms of the Creative Commons Attribution License 4.0 Author(s) retain the copyright of this article. Publication rights with Alkhaer Publications.

Published at: http://www.ijsciences.com/pub/issue/2017-08/

DOI: 10.18483/ijSci.1390; Online ISSN: 2305-3925; Print ISSN: 2410-4477 
forming amide bonds between the $\mathrm{NH}_{2}$ of one amino acid and the $\mathrm{COOH}$ of another [6]. For classification purposes, chains with fewer than fifty amino acids are often called peptides while the term protein is reserved for larger chains.

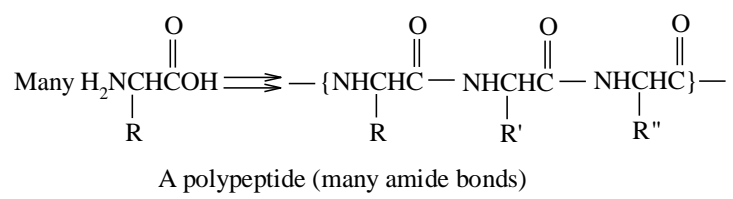

The twenty common amino acids can be classified as either neutral or acidic or basic depending on the structure of their side chain. Fifteen of the twenty have neutral side chains, two (aspartic and glutamic acids) have an extra carboxylic acid function in their side chains, and three (lysine, argnine and histidine) have basic amino groups in their side chains. All twenty of the amino acids are necessary for protein synthesis, but humans can synthesis only ten of the twenty. The remaining ten are called essential amino acids because they must be obtained from dietary sources [6]. Failure to include an adequate dietary supply of these essential amino acids can lead to deficiency diseases [7]. In acid solution at low $\mathrm{pH}$, an amino acid is protonated and exists primarily as a cation. In basic solution at high $\mathrm{pH}$, an amino acid is deprotonated and exists primarily as an anion. Thus, there must be some intermediate $\mathrm{pH}$ at which the amino acid is exactly balanced between anionic and cationic forms and exists primarily as the neutral, dipolar Zwitterions. This $\mathrm{pH}$ is called the amino acids isoelectric point.

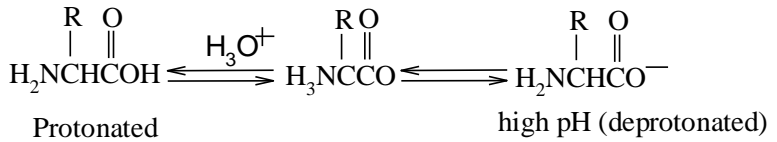

The legume seeds or pulses are second only to the cereals as a source of human food providing much needed proteins. They play an important role in the acceptability of monotonous diets in many parts of the world [8]. The legumes refer to the edible seeds of leguminous plant belonging to the leguminosae family. The ones used as food can be divided into two groups; the pulses and oilseeds. Pulses are the derived edible seed of cultivated legumes such as peas, beans and lentils. The second group, the oilseeds consist of those legumes used primarily for their oil content which may be extracted by pressing, thermal or solvent extraction. Examples are groundnut, gourdseed and soybeans [9, 10]. The efforts geared towards research on legumes are predicated on the fact that legumes have been established to be cheap but abundant sources of protein [11-16]. Therefore, this paper aims at reviewing critically published works on proteins and amino acid composition of some common legume foods found in Nigeria as dietary sources of proteins.

\section{Common Legume foods Grown in Nigeria}

Pigeon pea (Cajanus cajan L.) is a member of the Papilonidacea (Leguminacea). It is a deep rooted drought resistance perennial shrub grown throughout the world under different climatic and cultural conditions [17, 18]. In Nigeria, the plant has been listed as one of the underutilized legumes with broad potentials [19-22]. Several clinical studies have revealed the potential use of pigeon pea seed as melanin based in the dietary management of diabetes mellitus and cardiovascular diseases [23]. In Nigeria, the plant has recently been exploited for biscuit making [24].

Soybeans (Glycine max L.) is a leguminous plant of pulse family and a native to the tropical and warm temperate regions of the orient, where it has been cultivated as a principal crop for at least 5000 years. There are 2,500 varieties in cultivation. It is usually grown in the northern part of Nigeria. Soybeans are grown primarily for their protein content and secondarily for their oils [25-26].

Cowpea (Vigna unguiculata L.) is an important food legume in Africa and South-East Asia. It is thought to have originated from central Africa and is now grown in many parts of the tropics like West Africa, India and central Africa [27]. Cowpea is the most widely grown and distributed legumes in Nigeria. The chemical composition of cowpea is similar to that of most edible legumes. It contains about $24 \%$ crude protein, $62 \%$ carbohydrate and minute amount of other nutrients [28]. Various types of products are traditionally produced from cowpeas by soaking, dehulling, grinding, boiling or frying. It can be made into paste and fried or streamed to give "akara", "moi-moi" and "ekuru" in Southwest, Nigeria [2932]

Groundnut (Arachis hypogeal L.) is a species in the legume family Fabacea, native to South America [33]. It is an annual herbaceous plant growing up to $30-50 \mathrm{~cm}$ tall. Groundnuts grow best in light, sandy loam soil. Greater percentage of the annual production of groundnuts is produced from the northern part of Nigeria. There are many ways of preparing groundnuts for direct consumption by roasting or boiling or, for native dishes by fermentation roasting and homogenizing.

Bambara groundnut (Vigna subterranea L.) is one of the rural Africa's most popular grain legumes, ranking third in importance after groundnut (Arachis hypogaea L.) and cowpea (Vigna unguiculata L. Walpers) in sub-Saharan Africa [34-35]. It appears 
to have evolved in the savannas probably in West Africa and its compact habit seems to be an adoption to growing in hot, windy environment [10]. Different varieties of bambara groundnut are grown in the middle belt and northern parts of Nigeria [36].

Kersting's groundnut (Kerstingiella geocarpa L.) is an annual herb, which grows on sandy loam soils in savannah areas of West Africa through Senegal to Nigeria. It produces fruits which is a pod containing $1-3$ brownish seeds with a helium and a relatively thick test similar to that of groundnut [37].

African yam bean (Sphenostylis sternocarpa L.) is a drought tolerant legume crop grown primarily as a food grain. The major area of cultivation is West Africa, especially southern Nigeria. It grows well even on acid and highly leached sandy soils. The seeds are delicious and in West Africa, they are often preferred over other legume grains [38].

Scarlet runner bean (Phaseolus coccineus L.), a species of family Fabacceae, has been cultivated in the high parts of Mesoamerica. Its introduction into southern Columbia (Antioquia and Narino) and Europe where it is known as scarlet runner bean and haricot d'Espagne could have occurred in the seventeenth century before reaching other parts of the world such as the Ethiopian high lands [39-42]. Like other members of the Feabacceae, it possesses climbing stems. Its pods are gathered and left to dry in the sun before being beaten and the seeds are stored in sacks. They are cultivated by peasant farmers for home consumption in the middle belt of Nigeria. The aesthetic value of the seeds prompted their used in recreational activities such as traditional marriage in peasant communities among the Mada and Eggon tribes in Nigeria [43].

Lima bean (Phaseolus lunatus L.) has been cited as legume having exceptional potential for adaptation to lowland tropical conditions and as potentially important food legume [35]. It has a characteristic problem of being had to cook [21, 44].

White melon (Cucumeropsis): sweet melon (Cucumis) and water melon (Citrullus) are of the same genera in the family of Cucurbitaceae. There are many species and varieties in each genus of this family. They are widely grown in Nigeria. Species of this family are minor agricultural crops in Nigeria. The kernels of most species are used for food in different consumable forms $[16,45]$. Some are used as soup thickeners; e.g. in "Egwusi" soup, while some are fried and eaten as snacks or fermented traditionally to produce "Ogiri" - a flavouring agent for use as soup condiment [46].
Black turtle bean (Phaseolus vulgaris L.), a herbaceous animal plant is thought to have originated from ancient Mesoamerica and the Andes and is now grown in many parts of the tropics including West Africa. Black turtle beans are grown worldwide for its edibility and nutritional qualities. This crop is among lesser-known beans grown in Nigeria especially by the people of Bokkos in Plateau State [47]. The leaf of black turtle bean is occasionally used as leaf vegetable while the plant can be taken in the form of stew and the straw as a folder [47].

\section{Crude protein and amino acid composition of legume foods}

Protein contains mainly nitrogen; so nitrogen is used as an index of the protein termed "crude protein" as distinct from true protein. Both protein content and amino acid composition have been shown to vary considerably between families, genera, species and cultivars [48]. Variations in these parameters often exist between plants, depending on the developmental and growth stage. Micro variations in the protein and amino acid composition of individual seeds of a plant may occur, depending on the position of the seed in the fruiting organ and its location on the plant. Major differences in these values can be attributed to two principal factors; genetics and environment. These factors interact and the ultimate response obtained represents an amalgam of the many individual components concerned $[49,50]$.

When comparing analytical data for the protein and amino acid composition, it should always be borne in mind that the values often relate to a singly cultivar grown in a particular area in a particular year, and quite often under unique environmental conditions [51]. In addition, different analytical procedures may also have been employed in different laboratories, and frequently the analysis may have been performed as subsidiary part of the major investigation [48]. It is clear from these considerations that the values for protein and amino acid composition can only provide a relative indication of these components.

\section{Determination of crude protein}

The estimation of the total crude protein is much more frequently carried out than determination of individual protein or amino acids. Analytical methods for the determination of the total crude protein content of a food are empirical in nature and circumvent the need for isolation and direct quantification of the protein. The most common approach for this assay is based on the determination of the amount of nitrogen, which includes the minor fraction on non-protein nitrogen that is eventually disregarded. This is solely found in the amino acid constituents of the protein. Alternative tests measure other specific protein moieties such as peptide linkage or contain amino acids [52]. Most methods of 
determining nitrogen in foods are; Kjeldahl (macro/micro), Formol titration, Dye-binding, Lowry, Biuret and Spectroscopic (Infra-red, absorption) methods.

The selection of a method for the determination of protein varies according to availability of equipment, number of samples to be regularly examined, urgency to obtain results, degree of accuracy required and the homogeneity of the sample.

Generally, the crude protein content of seeds is obtained by determining the nitrogen, normally by Kjeldahl digestion procedure, multiplying percentage nitrogen value by 6.25 . The conversion factor of 6.25 is widely used, because a wide range of proteins of different origin do contain $16 \%$ nitrogen. Biological materials, however, contain other nitrogenous compounds apart from protein, and the nitrogen of these will also be included in crude protein estimates by the Kjeldahl procedure. These non-protein nitrogen compounds include soluble amino acids, nuclei acids, purine and pyrimidine bases and their derivatives and nitrogen bases in lipids, which in total may account for $10-15 \%$ of the total nitrogen in legume seeds [53]. Generally, between $85-90 \%$ of the total nitrogen of legume seeds is protein in origin. Although the conversion factor of 6.25 is routinely used, other more accurate figures have been derived from amino acid analysis. Thus, for some oil seeds, conversion factor used are; 5.3 for sunflower, 5.46 for peanuts, 5.71 for soybean and 5.67 for rapeseed [49].

\section{Determination of amino acids}

Hydrolysis of the samples with $6 \mathrm{MHCl}$ at $100^{\circ} \mathrm{C}$ overnight in the absence of air is carried out to break the peptide bonds of a protein. The procedure gives good results for the acid stable amino acids that is, all those commonly occurring in food proteins except cysteine, methionine and tryptophan which are labile under acid hydrolysis conditions and require separate methods of analysis. Cysteine and methionine amino acids are therefore first oxidized with performic acid under controlled conditions, to convert them into residues of cysteic acid and methionine-sulphone, respectively. These acid-stable amino acids are then freed from the protein by hydrolysis with hydrochloric acid. Hydrolysis of the sample with barium hydroxide in solution in the absence of air releases tryptophan with decomposition [54].

The chromatographic analysis of the hydrolyzed sample is performed on an automatic amino acid analyzer. The principle is based on fractionation of amino acids in ion-exchange resins column by elution with a discrete buffer system or carrier gas. The eluate is mixed with ninhydrin reagent, and the mixture is passed through the reaction vessel in a boiling water bath. After $15 \mathrm{~min}$ of which colour reaction had been developed, the emerging stream passes through the colorimeter and the absorbance is monitored at 57 and $440 \mathrm{~nm}$. A carrier gas is used. The eluate is passed into a detector (flame initiation detectors, thermal detector, etc.) and the response is monitored to give the spectrum containing peaks for various amino acids $[54,55]$.

\section{Protein content in the Nigerian legume foods}

Table 1 presents the results of crude protein of some Nigeria legume foods as determined by some researchers and scientists. The values of the crude protein range from $11.6 \%$ sample in Vigna subterranea to $52.6 \%$ sample in Phaseolus coccineus. Glucine max, Arachis hypogea and Phaseolus coccineus are rich in protein (40.0 $52.6 \%)$. Protein content of Cajanus cajan on average (20.6\%) compares favourably with that of Vigna unguiculata (23.4\%), Sphenostylis sternocarpa (22.5\%) and Phaseolus lunatus (21.9\%). The high protein content of Cajanus cajan has been ascribed to be an increase in some of its constituents, including antisickling agents (Cajanose) and phenyalanine [56]. This would subsequently make consumption of Cajanus cajan clinically beneficial in the management of sickle cell disorder. In Nigeria, the future promise of quality confectionery production from Cajanus cajan flour has been attributed to the high protein content of strains of Cajanus cajan in the country [24]. Table 1 also depicts variations in the crude protein of various legume foods which perhaps belonging to different botanical families. Considerable inter-specific variation in the protein content of oilseed legumes has been reported [49]. For example, in a study involving 14 wild species of Arachis hypogea, the protein content were found to vary between 19 and $35 \%$; while for a similar number of species of Lupinus, the range was $27-50 \%$. Intraspecific variations in protein content are also well known. Inter-varietal values for a sample of 21 cultivars, lines and varieties of Arachis hypogea ranged from $23.5-53.3 \%$ [49]. Such variability is important in breeding programmes aimed at optimizing both crop and protein yield [57]. The forgoing might account for wide crude protein variations in Vigna unguiculata and Vigna subterranea as reported by different researchers (Table 1). 
Table 1: The crude protein of some Nigerian legumes $(\%)$

\begin{tabular}{lcc}
\hline \multicolumn{1}{c}{ Legume } & Crude protein & Author(s) \\
\hline & 21.2 & {$[58]$} \\
Pigeon pea (Cajanus cajan) & 20.4 & {$[59]$} \\
& 20.6 & {$[60]$} \\
Soybean (Glycine max) & 23.11 & {$[21]$} \\
& 40.0 & {$[62]$} \\
Cowpea (Vigna unguiculata) & 40.4 & {$[63]$} \\
& 42.0 & {$[58]$} \\
Groundnut (Arachis hypogeal) & 26.5 & {$[59]$} \\
Bambara groundnut (Vigna subterranea) & 20.4 & {$[64]$} \\
Kersting's groundnut (Kerstingiella geocaarpa) & 12.4 & {$[30]$} \\
African yam bean (Sphenostylis sternocarpa) & 47.9 & {$[59]$} \\
Scarlet runner bean (Phaseolus coccineus) & 48.4 & {$[30]$} \\
Lima bean (Phaseolus lunatus) & 11.6 & {$[65]$} \\
Melon seed (Citrullus vulgaris & 14.0 & {$[66]$} \\
Black turtle bean (Phaseolus vulgaris & 22.5 & {$[21]$} \\
\hline
\end{tabular}

Table 2: The essential amino acids of some Nigerian legumes (g/100g crude protein)

\begin{tabular}{|c|c|c|c|c|c|c|c|c|c|c|c|}
\hline Legume & His & Ile & Leu & Lys & Met & Phe & Thr & Trp & Val & Arg & Author/s \\
\hline \multirow{4}{*}{ C. cajan } & 3.29 & 3.54 & 7.22 & 6.38 & 1.09 & 10.10 & 3.45 & 1.15 & 4.02 & 6.05 & {$[58]$} \\
\hline & - & 3.71 & 7.15 & 6.57 & 1.09 & 9.72 & 3.49 & 1.21 & 4.29 & nd & {$[68]$} \\
\hline & 2.13 & 2.38 & 4.75 & 4.38 & 0.94 & 5.44 & 2.13 & 0.30 & 3.13 & 4.19 & [60] \\
\hline & 4.85 & 4.46 & 7.67 & 6.32 & 2.66 & 8.21 & 6.42 & nd & 4.77 & 4.24 & [20] \\
\hline \multirow{4}{*}{ G. $\max$} & 2.40 & 4.80 & 7.90 & 6.00 & 1.20 & 5.50 & 3.60 & 1.00 & 4.70 & 7.80 & {$[63]$} \\
\hline & 2.60 & 4.60 & 7.80 & 6.40 & 1.10 & 5.00 & 3.90 & 1.40 & 4.60 & 7.30 & [69] \\
\hline & nd & 4.50 & 7.80 & 6.58 & 1.19 & 5.62 & 2.68 & 1.06 & 4.90 & nd & [61] \\
\hline & 3.00 & 5.90 & 7.60 & 6.20 & 1.10 & 5.80 & 3.70 & nd & 4.90 & 8.30 & {$[70]$} \\
\hline \multirow{4}{*}{ V. unguiculata } & 3.31 & 4.81 & 9.46 & 5.76 & 0.46 & 5.27 & 3.71 & nd & 7.07 & 4.29 & [71] \\
\hline & 2.80 & 3.92 & 7.19 & 6.70 & 1.20 & 5.63 & 3.65 & 1.07 & 4.44 & 8.07 & {$[58]$} \\
\hline & nd & 4.33 & 7.50 & 6.58 & 1.19 & 5.62 & 3.68 & 1.06 & 4.90 & nd & [68] \\
\hline & 3.04 & 3.52 & 7.30 & 6.84 & 1.02 & 3.49 & 3.75 & 9.62 & 4.15 & 7.23 & [64] \\
\hline \multirow{3}{*}{ A. hypogeal } & 2.00 & 3.08 & 5.93 & 2.80 & 1.71 & 3.70 & 2.29 & nd & 3.12 & 3.46 & [30] \\
\hline & 2.40 & 3.60 & 6.40 & 3.60 & 1.40 & 4.90 & 2.60 & 0.90 & 4.60 & 12.40 & {$[60]$} \\
\hline & 1.50 & 2.50 & 4.38 & 3.19 & 0.88 & 3.25 & 2.44 & 0.70 & 3.13 & 7.75 & [69] \\
\hline \multirow[b]{2}{*}{ V. subterranea } & nd & 4.40 & 7.80 & 6.40 & 1.80 & 5.60 & 3.50 & 1.10 & 5.30 & nd & [65] \\
\hline & 2.20 & 3.82 & 6.81 & 3.01 & 2.02 & 4.31 & 2.57 & nd & 3.83 & 4.03 & [72] \\
\hline K. geocaarpa & 2.31 & 3.83 & 6.80 & 3.04 & 2.04 & 4.22 & 2.53 & nd & 3.91 & 4.12 & [66] \\
\hline S. sternocarpa & 4.69 & 6.99 & 8.87 & 7.21 & 0.96 & 6.34 & 4.85 & nd & 7.12 & 6.10 & [21] \\
\hline P. coccineus & 2.00 & 3.78 & 6.63 & 3.10 & 1.91 & 4.00 & 3.23 & nd & 3.26 & 3.85 & [30] \\
\hline P. lunatus & 3.97 & 5.53 & 7.23 & 6.08 & 1.63 & 5.18 & nd & nd & 5.1 & 6.57 & [21] \\
\hline \multirow{2}{*}{ C. vulgaris } & 2.60 & 4.20 & 6.70 & 3.70 & 1.90 & 5.50 & 1.60 & nd & 5.00 & 16.00 & [16] \\
\hline & 0.96 & 2.20 & 3.62 & 1.85 & 1.42 & 3.22 & 1.84 & nd & 2.48 & 9.88 & [67] \\
\hline P. vulgaris & 3.20 & 4.10 & 7.70 & 6.50 & 1.30 & 4.20 & 2.90 & nd & 4.70 & 6.50 & [47] \\
\hline
\end{tabular}

nd $=$ not determined 
Amino acid composition of Nigerian legume foods The essential amino acids are shown in Table 2 while Table 3 depicts non-essential amino acids. Leucine (Leu) is the most concentrated essential amino acids in Nigerian legume foods, followed by arginine (Arg) which is essential for children aside histidine. The collected data indicate that aspartic (Asp) and glutamic (Glu) acids are the most abundant nonessential amino acids present in the legumes. Certain broad conclusions can be adduced from Tables 2 and 3. With minor exceptions, the amino acid compositions of the legume seeds resemble each other, indicating that generally, the major proteins (storage globulins) in the seed are similar. These proteins are richer in leucine (Leu) and arginine (Arg) but poorer in sulphur amino acids than the functional proteins. Nutritionally, legume seed proteins are regarded as being limiting in the sulphur amino acids, methionine and cysteine; while being adequate in the other essential amino acids (threonine, lencine, isoleucine, valine, lysine, histidine, tryptophan and arginine) [73 - 77]. Generally, the protein of the non-legume oilseeds are richer in sulphur amino acids than those of their legume counterparts and may be regarded as being nutritionally adequate in these amino acids $[16,78$ 79]. Arachis hypogeal, Kerstingiella geocarpa, Phaseolus coccineus and Citrullus vulgaris have low lysine content (Table 2). Such levels must be regarded as being nutritionally inadequate [49, $80-$ 81]. The total amino acids (TAA), total essential amino acids (TEAA), total non-essential amino acids (TNEAA), total acidic amino acids (TAAA), total basic amino acids (TBAA) and total neutral amino acids (TNAA) in some legume foods are shown in Table 4; while Table 5 presents percentage of these in them. Tryptophan and histidine which were not determined by some authors are not part of the evaluation in some cases. TEAA values range between $27.47 \mathrm{~g} / 100 \mathrm{~g}$ protein in Citrullus vulgaris to $67.08 \mathrm{~g} / 100 \mathrm{~g}$ protein in Cajanus cajan while TNEAA are $28.38 \mathrm{~g} / 100 \mathrm{~g}$ protein in Citrullus vulgaris to $59.10 \mathrm{~g} / 100 \mathrm{~g}$ protein in Glycine max. Generally, it is observed that the total essential amino acids (TEAA) with values of histidine and arginine which are known to be essential amino acids in children are about the same values with the total non-essential amino acid values of most of the legume foods under review. Percentage of TEAA values (with histidine) range from $41.28 \%$ in Phaseolus coccineus to $68.85 \%$ in Cajanus cajan while that of TNEAA are $31.50 \%$ in Cajanus cajan to $58.72 \%$ Phaseolus lunatus. Although, percentage composition of total essential amino acids in the legume foods are comparable to that of amino protein foods such as eggs, milk, fish and meat; they provide less essential amino acids with exception of histidine and phenylalanine [55, 82-86].

Table 3: The non-essential amino acids of some Nigerian legumes (g/100g crude protein)

\begin{tabular}{|c|c|c|c|c|c|c|c|c|c|}
\hline Legume & Cys & Tyr & Ala & Asp & Glu & Gly & Pro & Ser & Author(s) \\
\hline \multirow{5}{*}{ C. cajan } & 1.01 & 2.70 & 4.31 & 8.87 & 20.30 & 3.56 & 4.76 & 4.84 & [58] \\
\hline & 1.18 & nd & nd & nd & nd & nd & nd & nd & [68] \\
\hline & 0.75 & 2.10 & 2.00 & 6.28 & 7.75 & 1.07 & 8.65 & 7.51 & [60] \\
\hline & 2.13 & 3.20 & 4.98 & 11.54 & 18.60 & 3.22 & 6.32 & 5.72 & [21] \\
\hline & 1.20 & 3.80 & 3.90 & 12.60 & 22.40 & 4.10 & 5.40 & 5.70 & [63] \\
\hline \multirow{3}{*}{ G. $\max$} & 2.60 & 3.80 & 4.30 & nd & 11.80 & 4.30 & 5.50 & 5.77 & [69] \\
\hline & nd & 3.10 & nd & nd & nd & nd & nd & nd & [61] \\
\hline & 1.80 & 4.20 & 4.40 & 13.00 & 21.40 & 4.40 & 4.80 & 4.80 & {$[70]$} \\
\hline \multirow{4}{*}{$V$. unguiculata } & 1.01 & 3.13 & 4.30 & 12.60 & 18.70 & 4.30 & 3.41 & 6.05 & [58] \\
\hline & 0.03 & 0.56 & 6.89 & 12.30 & 21.30 & 4.82 & 5.58 & 5.77 & [71] \\
\hline & 2.55 & 2.92 & 4.97 & 12.20 & 16.90 & 3.95 & 4.50 & 5.49 & [64] \\
\hline & 0.40 & 2.63 & 2.94 & 5.13 & 15.82 & 3.03 & 3.72 & 2.38 & [30] \\
\hline \multirow{2}{*}{ A. hypogeal } & 1.50 & 3.80 & 3.90 & 11.60 & 19.30 & nd & 4.50 & 5.00 & [60] \\
\hline & 0.81 & 2.20 & nd & nd & nd & nd & nd & nd & {$[60]$} \\
\hline \multirow{2}{*}{$V$. subterranea } & 0.51 & 3.20 & 3.50 & 5.02 & 16.53 & 3.30 & 3.24 & 3.20 & [30] \\
\hline & 1.00 & 3.50 & nd & nd & nd & nd & nd & nd & [65] \\
\hline K. geocaarpa & 0.61 & 3.30 & 3.51 & 5.02 & 19.53 & 3.33 & 3.14 & 3.24 & [61] \\
\hline S. sternocarpa & 1.14 & 3.84 & 5.88 & 8.25 & 13.12 & 5.37 & 6.43 & 7.68 & [21] \\
\hline P. coccineus & 0.48 & 3.32 & 3.40 & 4.79 & 13.25 & 2.91 & 2.95 & 3.06 & [30] \\
\hline P. lunatus & 2.86 & 3.52 & 4.84 & 14.55 & 15.22 & 3.77 & 5.45 & 8.52 & [21] \\
\hline \multirow{2}{*}{ C. vulgaris } & nd & 3.50 & 5.20 & 11.40 & 18.10 & 6.70 & 4.30 & 3.40 & [16] \\
\hline & 1.85 & 1.75 & 2.62 & 4.69 & 9.57 & 3.14 & 2.06 & 2.70 & [67] \\
\hline P. vulgaris & 0.80 & 3.50 & 3.20 & 7.90 & 11.20 & 4.0 & 3.0 & 3.60 & [47] \\
\hline
\end{tabular}

nd $=$ not determined 
Table 4: Essential, non-essential, acidic, basic and neutral amino acids of some Nigerian legumes (g/100g crude protein)

\begin{tabular}{lcccccc}
\hline \multicolumn{1}{c}{ Food } & TAA & TEAA & TNEAA & TAAA & TBAA & TNAA \\
\hline C. cajan & 97.43 & 67.08 & 30.35 & 29.17 & 15.72 & 52.54 \\
& 65.88 & 29.77 & 36.11 & 14.03 & 10.70 & 41.15 \\
& 105.31 & 49.60 & 55.71 & 30.14 & 15.41 & 45.55 \\
G. max & 104.0 & 44.90 & 59.10 & 35.00 & 16.20 & 52.80 \\
& 82.5 & 44.70 & 37.80 & 11.80 & 15.96 & 54.74 \\
& 105.3 & 46.50 & 58.80 & 34.40 & 17.50 & 53.40 \\
V. unguiculata & 101.39 & 44.14 & 57.25 & 33.60 & 13.36 & 54.43 \\
& 95.17 & 41.67 & 53.50 & 31.30 & 17.57 & 46.30 \\
A. hypogeal & 103.44 & 49.96 & 53.48 & 29.10 & 17.11 & 57.23 \\
V. subterranea & 64.14 & 28.09 & 36.05 & 20.95 & 8.26 & 34.93 \\
K. geocaarpa & 76.36 & 42.80 & 33.56 & 30.90 & 18.40 & 27.06 \\
S. sternocarpa & 70.8 & 32.50 & 38.40 & 21.50 & 9.20 & 30.70 \\
P. coccineus & 74.2 & 32.70 & 41.40 & 24.50 & 9.40 & 40.30 \\
P. lunatus & 104.84 & 53.13 & 51.71 & 21.37 & 18.00 & 64.47 \\
C. vulgaris & 65.90 & 31.80 & 34.10 & 18.10 & 9.0 & 38.80 \\
P. vulgaris L. & 100.02 & 41.29 & 58.73 & 29.75 & 16.62 & 53.65 \\
\hline A Total aming & 115.8 & 63.20 & 52.60 & 29.50 & 22.30 & 64.0
\end{tabular}

TA $\mathbf{A}=$ Total amino acid; TEAA $=$ Total Essential amino acid; TNEAA $=$ Total non-essential amino acid; TAAA $=$ Total acidic amino acid; TBAA = Total basic amino acid; TNAA = Total neutral amino acid

Table 5: Percentage essential, non-essential, acidic, basic and neutral amino acids of some Nigerian legumes (g/100g crude protein)

\begin{tabular}{lccccc}
\hline \multicolumn{1}{c}{ Food } & TEAA & TNEAA & TAAA & TBAA & TNAA \\
\hline C. cajan & 68.85 & 31.50 & 29.94 & 16.13 & 53.93 \\
& 45.19 & 54.81 & 21.30 & 16.24 & 62.46 \\
G. max & 47.10 & 52.90 & 28.62 & 14.63 & 43.25 \\
& 43.17 & 56.83 & 33.65 & 15.58 & 50.77 \\
& 54.18 & 45.82 & 14.30 & 19.35 & 66.35 \\
V. unguiculata & 44.16 & 55.84 & 32.67 & 16.62 & 50.71 \\
& 43.53 & 56.47 & 33.14 & 13.18 & 53.48 \\
A. hypogeal & 43.78 & 56.22 & 32.89 & 18.46 & 48.65 \\
V. subterranea & 48.30 & 51.70 & 31.30 & 16.54 & 55.33 \\
K. geocaarpa & 43.79 & 56.21 & 32.66 & 12.88 & 54.46 \\
S. sternocarpa & 56.05 & 43.95 & 40.47 & 24.10 & 35.44 \\
P. coccineus & 45.90 & 54.20 & 30.40 & 13.0 & 43.36 \\
P. lunatus & 44.1 & 55.80 & 33.0 & 12.70 & 54.31 \\
C. vulgaris & 50.68 & 49.32 & 20.38 & 17.17 & 62.45 \\
P. vulgaris & 48.30 & 51.70 & 27.40 & 13.60 & 58.88 \\
\hline . & 41.28 & 58.72 & 29.74 & 16.62 & 53.64 \\
\hline
\end{tabular}

TEAA = Total Essential amino acid; TNEAA = Total non-essential amino acid; TAAA = Total acidic amino acid; TBAA = Total basic amino acid; TNAA = Total neutral amino acid 


\section{Conclusion}

The legumes used as foods are the edible seeds of leguminous plant belonging to the leguminosae family. The chemical and physical properties of legume seeds vary widely. The reviewed data have shown that the crude protein of legume foods ranges between 11.6 - 52.6\%. The most abundant amino acids are glutamic and aspartic acids. The percentage total essential amino acids (TEAA) range between 41.28 - $68.85 \%$, total non-essential amino acids (TNEAA) range between $31.50-58.72 \%$; while the total acidic amino acids (TAAA) are between 14.30 $40.47 \%$ for all the legumes reviewed. The legume seeds are low in sulphur amino acids, methionine and cystine but are high in lysince. Generally, legumes are great sources of most of the essential amino acids. Therefore, they are highly suitable for the fortification of cereal products mostly used as weaning foods for children in most Africa countries, including Nigeria.

\section{References}

1. Shakuntala, M. N., Shadaksharaw, M. \& Swamy, M. (1987). Foods Facts and Principles. Wiley Eastern Ltd. New Delhi, India.

2. Encyclopedia Americana (1972). Grolier Incorporated Copyright $\odot$.

3. Milner, M. (1981). Protein Resources in International Food Aid Programs. In: Utilization of Protein Resources; Stanley, D. W., Murray, E. D. \& Lees, D. H. (eds), Food and Nutrition Press.

4. Wikipedia Encyclopedia www.wikipediaencyclopedia.com.

5. Altschul, A. M. (1965). Protein: Their Chemistry and Politics. Chapman and Hall.

6. Fox, B. A. \& Cameron, A. G. (1970). Food Science: A Chemical Approach. University Press, London.

7. Powrie, W. D. \& Nakai, S. (1981). Processing Effects on Protein Systems. In: Utilization of Protein Resources. Stanley, D. W., Murray, E. D. \& Lees, D. H. (eds). Food and Nutrition Press.

8. Walker, A. F. \& Kocher, N. (1982). Effects of processing including domestic cooking on nutritional quality of legumes. Proc. Nutr. Soc., 41, $41-46$.

9. Aykroyd, W. R. \& Doughty, J. (1994). Legumes in Human Nutrition. FAO Nutrition Studies No. 19, FAO, Rome.

10. Duke, J. A. (1981). Handbook of legumes of World Economic importance, Plenum Press.

11. Akintayo, E. T., Oshodi, A. A. \& Esuoso, K. O. (1999). Effect of strength and $\mathrm{pH}$ on the faming and gelation of pigean pea (Cajanus cajan) protein concentrates. Food Chemistry, 66, $51-56$

12. Olaofe, O. \& Sanni, C. O. (1988). Mineral contents of agriculture products. Food Chem., 30, 73 - 77.

13. Aremu, M. O., Olonisakin, A., Bako, D. A. \& Madu, P. C. (2006d). Compositional studies and physicochemical characteristics of cashew nut (Anarcadium occidentale) flour. Pak. J. Nutri., 5(4), 328 - 333.

14. Adebowale, K. O. \& Lawal, O. S. (2004). Comparative study of the functional properties of bambara groundnut (Voandzeia subterranea), jack bean (Canavalia ensiformis) and mucuna bean (Mucuna pruriens) flours. Food Res. Int., $37,355-365$.

15. Aremu, M. O., Olaofe, O. \& Akintayo, E. T. (2005a). Nutritional qualities assessment of the presence of hull in some Nigerian underutilized legume seeds. Bulletin of Pure and Applied Sci., 24(1-2), 47 - 52.
16. Olaofe, O., Adeyemi, F. O. \& Adediran, G. O. (1994) Amino acid and mineral composition and functional properties of some oilseeds. J. Agric Food Chem., 42, 878 881 .

17. Akinola, J. O., Whiteman, P. C. \& Walls, E. S. (1975). The agronomy of pigeon pea (Cajanus cajan). Department of Agriculture, University of Queensland, St. Lucia Queensland, Australia, pp. $134-137$.

18. Summerfield, R. J. \& Roberts, E. H. (1985). Grain Legumes Crops (1st ed). London, Collins Professional \& Technical Books, pp. $658-659$.

19. Badifu, G. I. O. (1992). Food potential of some unconventional oilseed grown in Nigeria: A brief review. Plant Foods for Human Nutri., 43, 211 - 224.

20. Oshodi, A. A., Olaofe, O. \& Hall, G. M. (1993). Amino acid, fatty acid and mineral composition of pigeon pea (Cajanus cajan). Int. J. Food Sci. \& Nutri., 43, 187 - 191

21. Oshodi, A. A., Esuoso, K. O. \& Akintayo, E. T. (1998). Proximate and amino acid composition of some underutilized Nigeria legume flour and protein concentrate. La Rivista Italiana Delle Sustanze Grasse, LXXV, 409 - 412.

22. Oshodi, A. A. \& Ekperigin, M. M. (1989). Functional properties of pigeon pea (Cajanus cajan) flour. Food Chem., $34,187-191$.

23. Siegel, A. \& Fawcett, B. (1976). Food Legume Processing and Utilization, with Special Emphasis on Application in Developing Countries, IDRC, Ottawa.

24. Eneche, E. H. (1999). Biscuit making potential of millet/pigeon pea flour blends. Plant Food Humand Nutri., $54,21-27$.

25. Agboola, Y. A. \& Oguntuase, O. S. (2006). Effect of Baculus sphaericus on proximate composition of soybeans for the production of soy-iru. Pak. J. Nutri., 5(6), $606-609$.

26. Ihekoronye, A. I. \& Ngoddy, P. O. (1985). Integrated Food Science and Technology for the Tropics. Macmillan Publisher, London, pp. $28-50$.

27. Desonck, D. G. (1991). Systematic and Morphology. In: Van Schoonhoven, A. and Voysest, O. (Eds.). Common Beans Research for Crop Improvement. CAB International, Wallingford, UK, pp. $55-118$.

28. Nnanyelugo, D. O., King, J., Ene-Obong, H. N. \& Ngoddy, P. O. (1995). Seasonal variation and the contribution on cowpea (Vigna unguiculata) and other legues to nutrient intake in Anambra State, Nigeria. Ecology, Food Nutri., 17, $271-281$.

29. McWatters, K. H. \& Brantley, B. B. (1982). Characteristic of "Akara" prepared from cowpea paste and meal food. Technology, 36, 66-68.

30. Aremu, M. O., Olaofe, O. \& Akintayo, E. T. (2006a) Compositional evaluation of cowpea (Vigna unguiculata) and scarlet runner bean (Phaseolus coccineus) varieties grown in Nigeria. J. Food, Agric \& Environ., 4(2), 39 - 46.

31. Aletor, V. A. \& Aladetimi, O. O. (1989). Compositional evaluation of some cowpea varieties and some underutilized legumes in Nigeria. Die Nahrung, 33(10), 99 - 107.

32. Aremu, M. O., Olaofe, O. \& Olonisakin, A. (2005b). Nutritional valuable mineral contents of two varieties of maize (Zea mays) produced in Ilorin, Kwara State, Nigeria. J. Ultra Chem., 1(2), $87-90$

33. Haines, C. P. (1991). Insects and arachnids of tropical stored products: Their biology and identification. Natural Resources Institute, Chatham, Kent, UK.

34. Doku, E. V. \& karikari, S. K. (1971). Bambara groundnut. Economic Botany, 25, 3 - 5.

35. Rachie, K. O. \& Silvestre, P. (1977). Grain Legumes. In: Crops of the Lowland Tropics. Leakey, C. L. A. \& Willis, J. B. (eds). Oxford University Press, London, p. 44.

36. Aremu, M. O., Mamman, S. \& Olonisakin, A. (2013). Evaluation of fatty acids and physicochemical characteristics of six varieties of bambara groundnut (Vigna subterranea L. Verdc.) seed oils. La Rivista Italiana Delle Sostanze Grasse, 90: 107-113.

37. Tindall, H. D. (1986). Vegetables in the Tropics. Macmillan Edu. Ltd. Hampshire, pp. $267-278$. 
38. Abbey, B. W. \& Ayuh, E. J. (1991). Functional properties of the African yam bean flour. Nig. J. Nutri., 12, $44-47$.

39. Kaplan, L. \& Kaplan L. (1988). Phaseolus in archaeology. In: Genetic Resources of Phaseolus beans. Gept, P. (eds). Khrwer Academic, Dordvocht. The Netherlands, pp. $125-$ 142.

40. Delgawo, S. A. (1985). Systematics of the Genus Phaseolus (Leguminosae) in North and Central America, Ph.D Thesis. University of Texas, Austin, USA.

41. Hernandez, X. E., Collins, M. \& Prywar, C. (1959). Elorigende Phaseolus coccineus L. derwimalus Hdzx and Mivanda C. subspecies nova. Rev. Soc. Men. Hist. Nt., 20(14), $99-121$

42. Elias, L. G., Cvistales, F. R., Bressani, R. \& Mivanda, H. (1976). Chemical composition and nutritive value of some grain legumes nutrient. Abs. Rev. (Series B/1977), 47, $603-$ 610.

43. Aremu, M. O., Olaofe, O. \& Orjioke, C. A. (2008a) Proximate and amino acid composition of bambara groundnut (Vigna subterranea), kersting's groundnut (Kerstingiella geocarpa) and scarlet runner bean (Phaseolus coccineus) protein concentrates. La Rivista Italiana Delle Sostanze Grasse, LXXXV, 56 - 62 .

44. Aremu, M. O., Salau, R. A., Olowoniyi, F. D., Ambo, I. A., Ombugadu, R. J. \& Maxwell, C. K. (2010). Chemical analyses and food properties of lima bean (Phaseolus lunatus L.) flour, Int. J. Chem. Sci., 3(1): $83-93$.

45. Akindele, A. M. (1978). Studies on "Ogiri", a Nigerian fermented melon seed condiment. M.Sc Thesis University of Ile-Ife, Nigeria.

46. Ogundana, S. K. (1980). The production of "Ogiri", a Nigerian fermented soup condiment. Lebensm-WissllTechn., 13, $334-336$.

47. Audu, S. S., Aremu, M. O. \& Lajide, L. (2013). Influence of traditional processing on the nutritional composition of black turtle bean (Phaseolus vulgaris L.) grown in Nigeria. Int. Food Res. J., 20: 3211 - 3220.

48. Mosse, J. \& Baudet, J. (1983). Crude protein content and amino acid composition of seeds, variability and correlations. Qual. Plant Foods Hum. Nutr., 32, 225 - 245.

49. Mosse, J. \& Pernollet, J. C. (1983). Storage proteins of legume seeds. In: Chemistry and Biochemistry of Legumes. Arora, S. K. (ed.), Edward Arnold, London, pp. $111-193$.

50. Muller, H. P. (1983). The genetic control of seed protein production in legumes. In: Seed Proteins, Biochemistry, genetics, Nutritive Value. Gottschalk, W. \& Muller, H. P. (eds.). Martinus Nijhoff-Junk. Hagne, Boston, pp. $309-353$.

51. Nielsen, N. C. (1984). The chemistry of legume storage proteins. Philos. Trans. R. Soc. London. B. Biol. Sci., 304, $287-296$.

52. Rosenthal, L. (1991). Milk and Dairy Products: Properties and Processing. Balatan Publication, New York, pp. 47 - 49.

53. Pearson, D. (1976). Chemical Analysis of Foods (7th edn.); London, Churchill Livingstone.

54. Spackman, D. H., Stein, W. H. \& More, S. (1958). Automatic recording apparatus for use in the chromatography of amino acids. Anal. Chem., 301, $1190-1206$.

55. Aremu, M. O. \& Ekunode, O. E. (2008b). nutritional evaluation and functional properties of Clarias lazera (African catfish) from River Tammah in Nasarawa State, Nigeria. Amer. J. Food Tech., 3(4), 264 - 274.

56. Ekeke, G. I. \& Shode, E. O. (1990). Phenyklanine, the predominant antisickling agent in Cajanus cajan seed extract. Plant Media, 56, 41 - 43 .

57. Bhatty, R. S., Sosulski, F. W. \& Wu, K. K. (1973). Protein and non-protein nitrogen contents of some oilseeds and peas. Canadian J. Plant Sci., 53(3), $651-657$.

58. Ene-Obong, H. N. \& Carnovale, E. D. (1992). A composition of the proximate, mineral and amino acid of some lesser known legumes in Nigeria. Food Chem., 43, 169 -175 .

59. Nnenna, J. E. (1998). Foods of Plant Origin. Afro-Orbis Publication Ltd. Nigeria, pp. 4 - 7.
60. Oyenuga, V. A. (1968). Nigerian Foods and Feeding Stuff, 3rd edn. Nigeria University Press, Ibadan, p. 35.

61. Singh, S. R., Rachie, K. O. \& Dashiell, K. E. (1989). Soybean for the Tropics. John Wiley and Sons Ltd, pp. $149-$ 160.

62. Salunkhe, D. K., Chavan, J. C., adsule, R. N. \& Kadam, S. S. (1992). World Oilseeds, Chemistry and Utilization. An Avi Book Published by Van Nostrand Reinhold, New York.

63. Fukunshima, D. (1991). Recent Progress of soybeans protein food chemistry, technology and nutrition. Food Rev. Int., 3, $323-351$.

64. West, C. E., Pepping, F. \& Temaliwa, C. R. (1988). The Composition of Foods, Commonly Eaten in Eat Africa. Wageninger Agricultural University.

65. Salunkhe, D. K., Kadam, S. S. \& Chavan, J. K. (1985). CRC Postharvest Biotechnology of Food legumes. CRC, Prss Boca Raton, FL.

66. Aremu, M. O., Olaofe, O. \& Akintayo, E. T. (2006c). A comparative study on the chemical and amino acid composition of some Nigerian underutilized legume flours. Pak. J. Nutri., 5(1), $34-38$.

67. Akobundu, E. N. T, Cherry, J. P. \& Summon, J. G. (1982) Chemical, functional and nutritional properties of egusi (Colocythis citrullus L.) seed protein products. J. Food Sci., $47,829-434$.

68. Splittstoesser, W. E., Martin, F. N. \& Rhodes, A. M. (1973) The amino acid composition of fire yam species (Dioscorea ssp). J. Amer. Sol. Hort. Sci., 98, 563 - 567.

69. Iwe, M. O., Van Znilichem, Lammers, W. \& Ngoddy, P. O. (2001). Amino acid and protein despersibility index (PDI) of mixtures of extruded soy and sweet potato flours. Lenbenson-Wiss U-Tech., 34, $71-75$.

70. Aisegbu, J. E. (1987). Some biochemical evaluation of fluted pumpkin seed. J. Sci. Food Agric, 40, $151-155$.

71. Olaofe, O., Umar, Y. O. \& Adediran, G. O. (1993). The effect of nematicids on the nutritive value and functional properties of cowpea seeds. Food Chem., 46, $337-342$.

72. Aremu, M. O., Olaofe, O. \& Akintayo, E. T. (2006b) Mineral and amino acid composition of two varieties of bambara groundnut (Vigna subterranea) and kersting's groundnut (Kerstingiella geocarpa) flour. Int. J. Chem., 16, $57-64$.

73. Sanchez-Vioque, R., Clemente, A., Vioque, J., Bautista, J. \& Millan, F. (1999). Protein isolates from hickpea (Cier arietinum L.): Chemical composition, functional properties and protein characterization. Food Chemistry, 64, $237-243$.

74. Olaofe, O., Akintayo, E. T., Adeyeye, E. I. \& Adubiaro, H. O. (2006). Proximate composition and functional properties of bulma cotton (Bombcapsis glasbra) seeds. Egypt J. Food Sci., $34,81-90$.

75. Aremu, M. O., Olonisakin, A., Atolaiye, B. O. \& Ogbu, C. F. (2007). Some nutritional composition and functional properties of Prosopis africana. Bangladesh J. Sci. Ind. Res., 42(3), $269-280$.

76. Audu, S. S. \& Aremu, M. O. (2011). Effect of processing on chemical composition of red kidney bean (Phaseolus vulagaris L.) flour. Pak. J. Nutri., 10(11): 1069 - 1075.

77. Aremu, M. O., Awala, E. Y., Opaluwa, O. D., Odoh, R. \& Bamidele, T. O. (2015). Effect of processing on nutritional composition of African locust bean (Parkia biglobosa) and mesquite bean (Prosopis africana) seeds. Communication in Applied Sciences, 3(1): 22-41

78. Fagbemi, T. N. \& Oshodi, A. A. (1991). Chemical composition and properties of full fat fluted pumpkin (Talfairia occidentalis) seed flour. Nig. Food J., 9, 26-31.

79. Audu, S. S., Aremu, M. O. \& Lajide, L. (2013). Effect of processing on physicochemical and anti-nutritional properties of black turtle beans (Phaseolus vulgaris L.) seeds flour. Oriental J. Chem., 29(3): 979 - 989.

80. Adeyeye, E. I. (2004). The chemical composition of liquid and solid endosperm of ripe coconut. Oriental J. Chem., 20, $471-478$

81. Oshodi, A. A., Ogungbenle, H. N. \& Oladimeji, M. O. (1999). Chemical composition, nutritionally valuable 
minerals and functional properties of benniseed (Sesamum radiatum), pearl millet (Pennisetum typhoides) and quinoa (Chenopodium quinoa) flours. Int. J. Food Sci., 50, 325 331.

82. Olaofe, O. \& Akintayo, E. T. (2000). Prediction of isoelectric points of legume and oilseed proteins from their amino acid composition. J. Technoscience, 4, $49-53$.

83. Coulate, T. P. (1982). Food: The Chemistry of its Components. Royal Society of Chemistry, London, pp. 76 77.

84. Aremu, M. O., Bamidele, T. O., Mohammed, Y., Opaluwa, O. D., Bako, S. S. \& Ramalan, F. (2011). Amino acid components important for health from animal protein sources. NSUK J. Sci. \& Tech., 1(1\&2): $94-100$.

85. Aremu, M. O., Namo, S. B., Oko, O. J., Adelagun, R. O. A \& Yebpella, G. G. (2014). Comparative evaluation of local smoked Nigerian mackerel (Scomber scombrus). J. Food Sci. \& Quality Mgt., 24: $42-50$.

86. Aremu, M. O., Namo, B. S., Mohammed, Y., Archibong, C. S. \& Ogah, E. (2014). Effect of different sources of heat on nutritional composition of tilapia fish (Oreochromis niloticus). Chemistry and Materials Res., 6(5): 85 - 93. 